\title{
CANOLA BIODIESEL: AN EXPERIMENTAL INVESTIGATION FOR PRODUCTION OF BIODIESEL AND PERFORMANCE MEASUREMENT IN DIESEL ENGINE
}

\author{
Amrinder Mehta ${ }^{1}$, Sandeep Kumar Duran ${ }^{2}$ \\ ${ }^{1}$ M.Tech Research Scholar, Department of Mechanical Engineering, Lovely Professional University, India \\ ${ }^{2}$ Assistant Professor, Department of Mechanical Engineering, Lovely Professional University India
}

\begin{abstract}
The experimental investigation was made to estimate the performance of methyl esters of Canola waste cooking oil and their blends in a direct injection diesel engine. The Canola waste cooking oil methyl ester (CWCOME) was prepared through transesterification process by using methanol and $\mathrm{KOH}$ as a catalyst. The Canola biodiesel blends were ready in proportion of 10\%, 20\%, 30\% and 100\% of biodiesel with diesel. The effects of pure biodiesel and their blends on engine performance, and exhaust emission were studied under various loading conditions. The experimental results concluded that up to $20 \%$ of methyl esters did not affect the performance parameter like fuel consumption rate and brake thermal efficiency. On the other hand above CB20 (20\% Canola biodiesel with 80\% diesel) a decrease in performance and combustion parameter were clearly observed form the study.
\end{abstract}

Keywords: Canola waste cooking oil, Canola methyl ester, Transesterification, Internal combustion engine, Engine performance.

\section{INTRODUCTION}

In the world at present time petroleum based fuels are at limited reserves but demand are continuously rise so the price in global market nonstop rise. The another major global concern climate change causes of global warming and the threat of supply fuel oil uncertainties have adversely affect the developing countries. Today the major portion of energy comes from fossil fuels. The developing concern on environmental pollution caused by the wide use of conventional fossil fuels has led to examine for additional environment friendly and renewable fuels. The biodiesel is one of the best alternative fuels which prepared from vegetable oil, animal fats, and recycled cooking oil. Biodiesel is renewable and environmental friendly alternative diesel fuel. The technical definition of biodiesel is mono alkyl esters of long fatty acids. The most important method to produce biodiesel is called transesterification. Through transesterification process separate the glycerin as a byproduct by using potassium hydroxide and methanol. Properties of biodiesel vary depending upon the plant source and fat source. That is basically related to the chemical composition as like number of carbon content and number of double bonds in hydrocarbon chain reaction. The biodiesel has produce $50 \%$ less hydrocarbons as compared diesel fuel, during the exhaust emission the biodiesel has produce few amount of sulfur oxide as compared diesel. On the other hand environment conversion and control of greenhouse gas (GHG) emissions have inspired for R\&D on biofuels. The Biofuels such as alcohols and biodiesel have been proposed as alternatives for internal combustion engines [1]. The several methods such as blending, transesterification, preheating and additional super critical methods are existing to treat the molecular structure of vegetable oils and animal fats [2]. The Canola quality and varieties are generally developed two species of Brassica napus and Brassica campestris. Several researches have used Methyl esters of, karanja and rapeseed oil [3,4], castor oil [5], corn oil [6], cottonseed oil, Effect of Cottonseed oil Methyl ester on the Performance and Exhaust Emissions of a vehicles, [7].

The main objective of this research was production of biodiesel and to check the performance and exhaust emission temperature at four stroke single cylinder, direct injection, water cooled diesel engine and fuel which has used such as diesel, Canola biodiesel and blends of biodiesel in percentage of $10,20,30$, and 100 percent by volume at variable load condition $20 \%, 40 \%, 60 \%, 80 \%$ and $100 \%$ load at engine.

\section{MATERIALS AND METHODS}

\subsection{Biodiesel Production}

The waste cooking Canola oil was collected from the local area. 


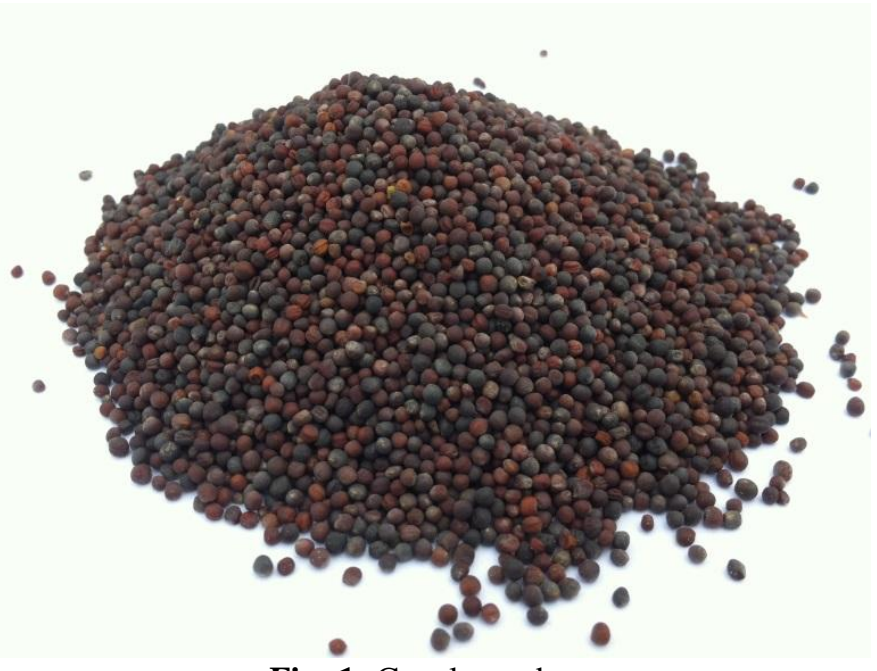

Fig -1: Canola seeds.

\subsubsection{Process Requirements}

1) Revolutions of stirrer: $600-700 \mathrm{rpm}$

2) Temperature of reaction: $65-700 \mathrm{C}$

3) Oil sample: $1000 \mathrm{ml}$

4) Methanol used: $250 \mathrm{ml} /$ liter of vegetable oil

5) $\mathrm{KOH}: 4.5 \mathrm{gm} /$ liter of vegetable oil

6) Reaction time : 2 hours

7) Sulphuric acid :1.0 ml/liter of vegetable oil

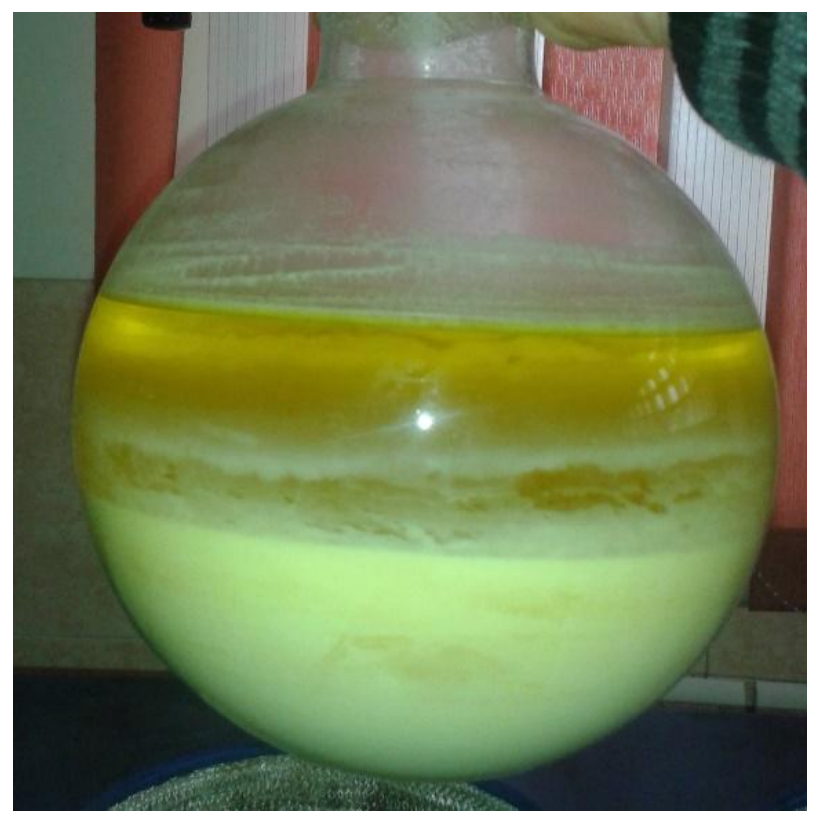

Fig -2: Gravity separation.

\subsubsection{Transesterification Procedure}

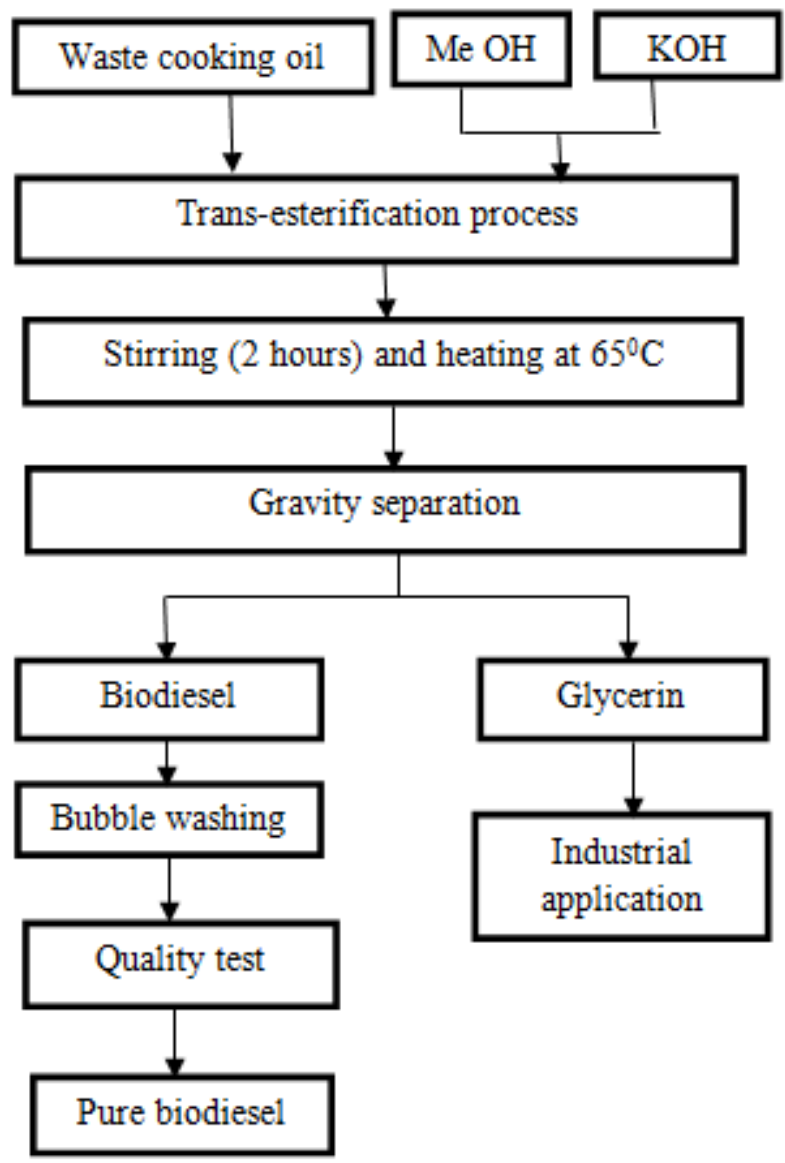

Fig -3: Basic transesterification process.

The mixing of potassium hydroxide and methanol was formed potassium meth-oxide. For preparation of 1 liter of biodiesel, $250 \mathrm{ml}$ methanol and $4.5 \mathrm{gm}$ of potassium hydroxide was used.

\section{Catalyst}

Triglyceride + Methanol $\longrightarrow$ Methyl esters + Glycerol

$$
\begin{array}{cc}
\mathrm{CH}_{2}-\mathrm{OCOR}^{1} & \mathrm{CH}_{2}-\mathrm{OH} \\
\mathrm{CH}_{2}-\mathrm{OCOR}^{2}+3 \mathrm{CH}_{2} \mathrm{OH} \rightarrow 3 \mathrm{RCOOCH}_{3}+\mathrm{CH}-\mathrm{OH} \\
\mid \\
\mathrm{CH} 2-\mathrm{OCOR}^{3} & \mid \\
\mathrm{CH}_{2}-\mathrm{OH}
\end{array}
$$



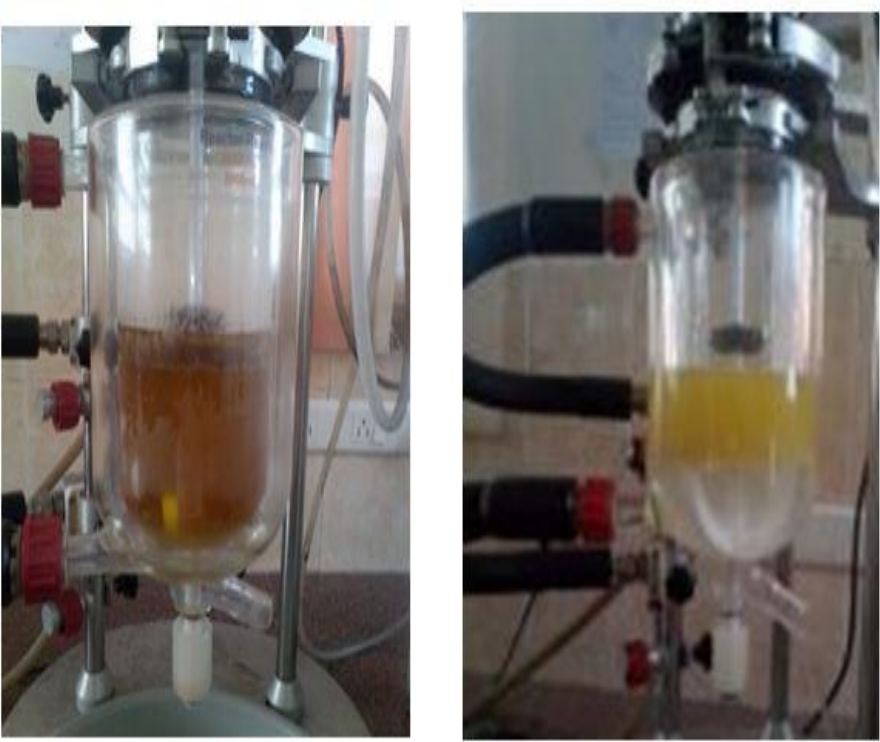

Fig -4: Biodiesel Reactor before the transesterification start and after the transesterification.

The mixture was stirred at $600 \mathrm{rpm}$ for 2 hours and maintaining temperature of reactor was $65^{\circ} \mathrm{C}$, the mixture of Canola methyl ester were allowed to settle down for 8 hours in flask, glycerin was heavier in weight as compared to biodiesel so that glycerin settles down and gravity separation method the Crude biodiesel obtained while had some impurities present, then separated by using bubble washing method and after it biodiesel again heated at $105^{\circ} \mathrm{C}$ temperature for remove moisture contents in biodiesel and after it check properties in quality test if biodiesel clearance ASTM D6751 standards the pure biodiesel obtained and it ready for use in direct injection diesel engine. The line diagram shows at Fig-2 the general procedure of making biodiesel in step by step techniques.

\subsection{Experimentation}

\subsubsection{Experimental Fuels}

In this research investigation five blends were prepared $10 \%$ $(\mathrm{v} / \mathrm{v})$ canola biodiesel with $90 \%(\mathrm{v} / \mathrm{v})$ diesel fuel denoted by CB10 (Canola biodiesel blend).

The pour point and cloud point of Canola biodiesel is higher so it can perform better work at cold condition as compare to diesel.

Table -1: Properties of diesel and Canola biodiesel blends

\begin{tabular}{|l|l|l|l|l|l|l|}
\hline S. No. & PROPERTIES & DIESEL & CB10 & CB20 & CB30 & CB100 \\
\hline 1. & Density at $15^{\circ} \mathrm{C}\left(\mathrm{kg} / \mathrm{m}^{3}\right)$ & 830 & 833 & 839 & 848 & 877 \\
\hline 2. & Viscosity at $40^{\circ} \mathrm{C}(\mathrm{cST})$ & 2.70 & 3.09 & 3.13 & 3.37 & 5.94 \\
\hline 3. & Flash point $\left({ }^{\circ} \mathrm{C}\right)$ & 58 & 75 & 82 & 95 & 156 \\
\hline 4. & Fire point $\left({ }^{\circ} \mathrm{C}\right)$ & 77 & 84 & 87 & 111 & 175 \\
\hline 5. & Calorific value $(\mathrm{MJ} / \mathrm{kg})$ & 43.09 & 41.11 & 40.95 & 39.96 & 37.45 \\
\hline 6. & Pour point $\left({ }^{\circ} \mathrm{C}\right)$ & 3.1 & 3.4 & 3.7 & 4.25 & 5.26 \\
\hline 7. & Cloud point $\left({ }^{\circ} \mathrm{C}\right)$ & 6.8 & 7.55 & 7.87 & 9.78 & 12.44 \\
\hline
\end{tabular}

After examined the properties of pure Canola biodiesel (CB100) and its blends (CB10, CB20, CB30) has satisfied result obtained as per ASTM D-6751, EN-14214, and IS15607 standards of biofuels policy.

\subsubsection{Experimental Setup and Procedure}

The four stroke single cylinder, direct injection, water cooled diesel engine was used for the performance tests. The specification of the test engine is shown in below Table-1. The experiments were carried out by initially using neat diesel fuel to generate the base line data. After recording the base line data, the test were carried out by using the biodiesel CB100 and its blends CB10, CB20, CB30.

The performance test were conducted at variable loads start from $20 \%, 40 \%, 60 \%, 80 \%, 100 \%$ loads at speed of engine was constant at $1500 \mathrm{rpm}$. During the testing diesel,

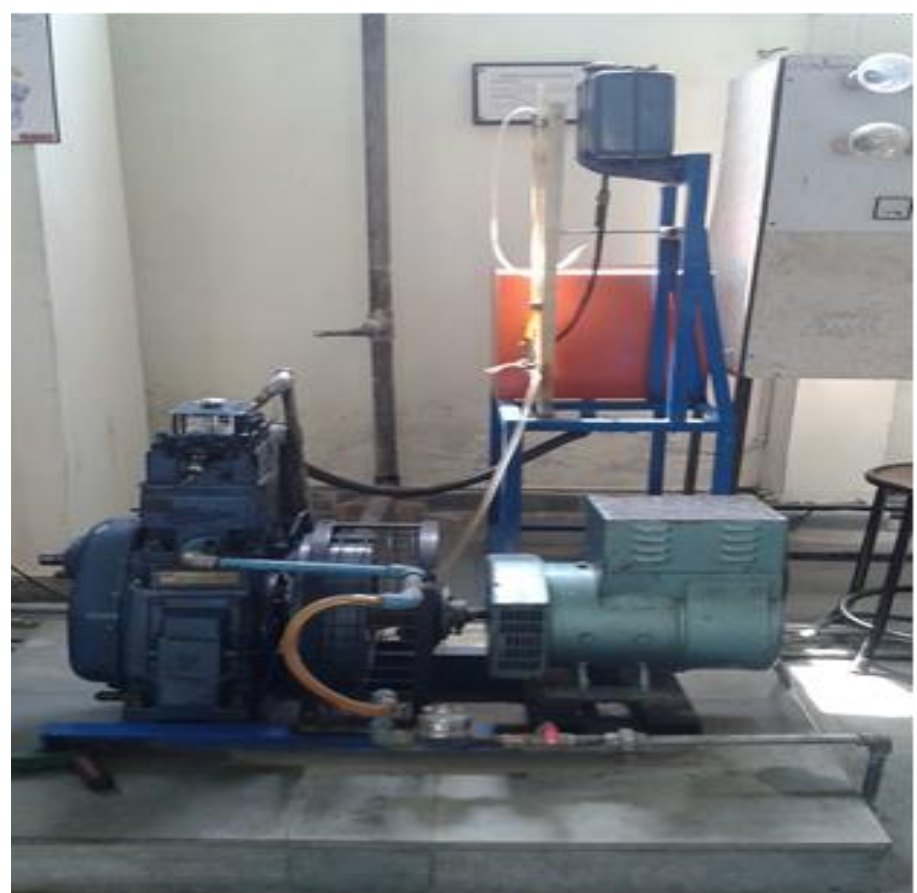

Fig -5: Experimental setup. 
Table -1: Engine Specification.

\begin{tabular}{|l|l|}
\hline Manufacturer & $\begin{array}{l}\text { Kirloskar engine Ltd, } \\
\text { Pune, India }\end{array}$ \\
\hline Engine type & $\begin{array}{l}\text { Single Cylinder, Four stroke, } \\
\text { cost and speed, compression } \\
\text { ignition engine }\end{array}$ \\
\hline Rated power & $5.2 \mathrm{~kW} \mathrm{@} \mathrm{1500} \mathrm{rpm}$ \\
\hline Bore & $87.5 \mathrm{~mm}$ \\
\hline Stroke & $110 \mathrm{~mm}$ \\
\hline Swept volume & $558 \mathrm{cc}$ \\
\hline Compression ratio & $17: 1$ \\
\hline Model of injection & Direct injection \\
\hline Dynamometer & Eddy current dynamometer \\
\hline Cooling system & Water \\
\hline Nozzle opening pressure & 200 to 205 bar \\
\hline
\end{tabular}

Biodiesel and its blends engine was run at least 30 minutes because the previous fuel is completely burnt. The following some important parameter were calculated

- $\quad$ Brake power, $\mathrm{kW}$

- $\quad$ Fuel consumption, $\mathrm{kg} / \mathrm{hr}$

- $\quad$ Exhaust gas temperature, ${ }^{\circ} \mathrm{C}$

\section{RESULTS AND DISCUSSION}

\subsection{Performance Characteristics}

\subsubsection{Brake Thermal Efficiency}

The brake thermal efficiency is the ratio of power output of the engine to rate of heat liberated by the fuel during the combustion. As shown in Fig-5, it is observed that as the load increases there is considerable increase in brake thermal efficiency. The brake thermal efficiency at $20 \%$ load for diesel CB 100, CB 30, CB 20, CB 10, was $14.52 \%$, $14.72 \%, 15.5 \%, 14.75 \%$, and $14.13 \%$, respectively. At $20 \%$ and $40 \%$ loading condition, the Canola biodiesel and all its blends have higher brake thermal efficiency than diesel. This happens because Canola biodiesel have containing 10\% more oxygen content than diesel. But at 60\%, $80 \%$ and $100 \%$ loading condition the Canola biodiesel and it's all blends have lower brake thermal efficiency than diesel.

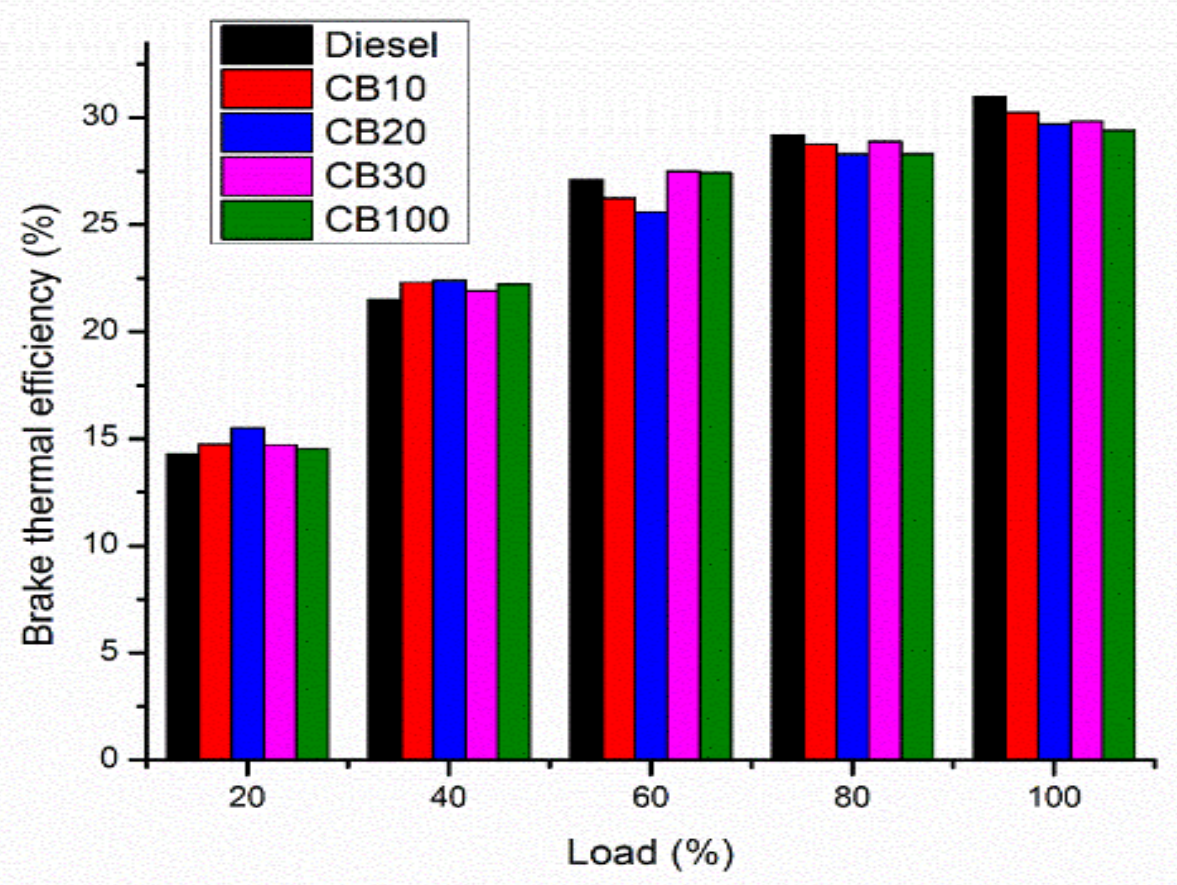

Fig -6: Brake thermal efficiency v/s Load

This happens due to calorific value $(39.83 \mathrm{MJ} / \mathrm{kg}$ ) of Canola biodiesel and the calorific value (44.18) of pure diesel. After examine results obtained at all loading condition CB20 is the best blend because brake thermal efficiency near about pure diesel.

\subsubsection{Fuel Consumption}

The variation of fuel consumption with load for diesel, and Canola biodiesel oil and its blends are shown in Fig-6. Fuel consumption for CB20, CB30 and CB100 blends has lower fuel consumption at $20 \%$ and $40 \%$ loads, because the biodiesel has present $10 \%$ more oxygen content so better fuel combustion takes place as compare to diesel, but at $60 \%, 80 \%, 100 \%$, loads the biodiesel fuel consumption is higher than diesel, because biodiesel has lower calorific value as compare to diesel fuel, but the result has shown CB20 is perform the best results in less fuel consumption at lower loads and higher loads condition. 


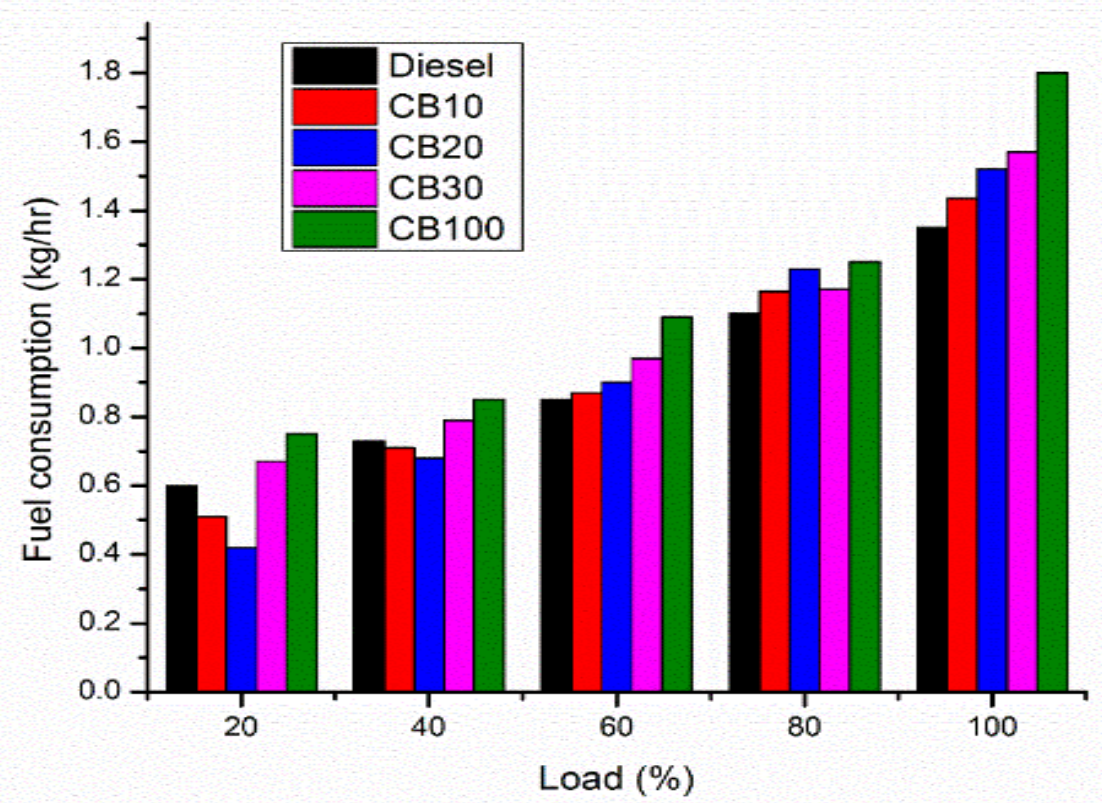

Fig -7: Fuel consumption v/s Load

\subsubsection{Exhaust Gas Temperature}

The variation of exhaust gas temperature was depending upon variation of $20 \%, 40 \%, 60 \%, 80 \%$, and $100 \%$ loads at engine. The graph has shown in Fig-7, exhaust gas temperature of pure Canola biodiesel and its blends are lower than diesel. It is observed that at all loads condition exhaust gas temperature of $\mathrm{CB} 30$ has minimum so it decrease NOx emission. The biodiesel has present $10 \%$ oxygen content so it reduce such harmful gases generation, hydrocarbons, carbon monoxide because the atmospheric air has present $21 \%$ oxygen contents, $78 \%$ nitrogen contents and $1 \%$ of other gases so unburnt fuel has left during combustion process takes place in combustion chamber and due to exit these unburnt fuel particle create high degree exhaust gas temperature which create harmful effect in ozone layer, so the of Canola biodiesel given better results in exhaust emission than diesel.

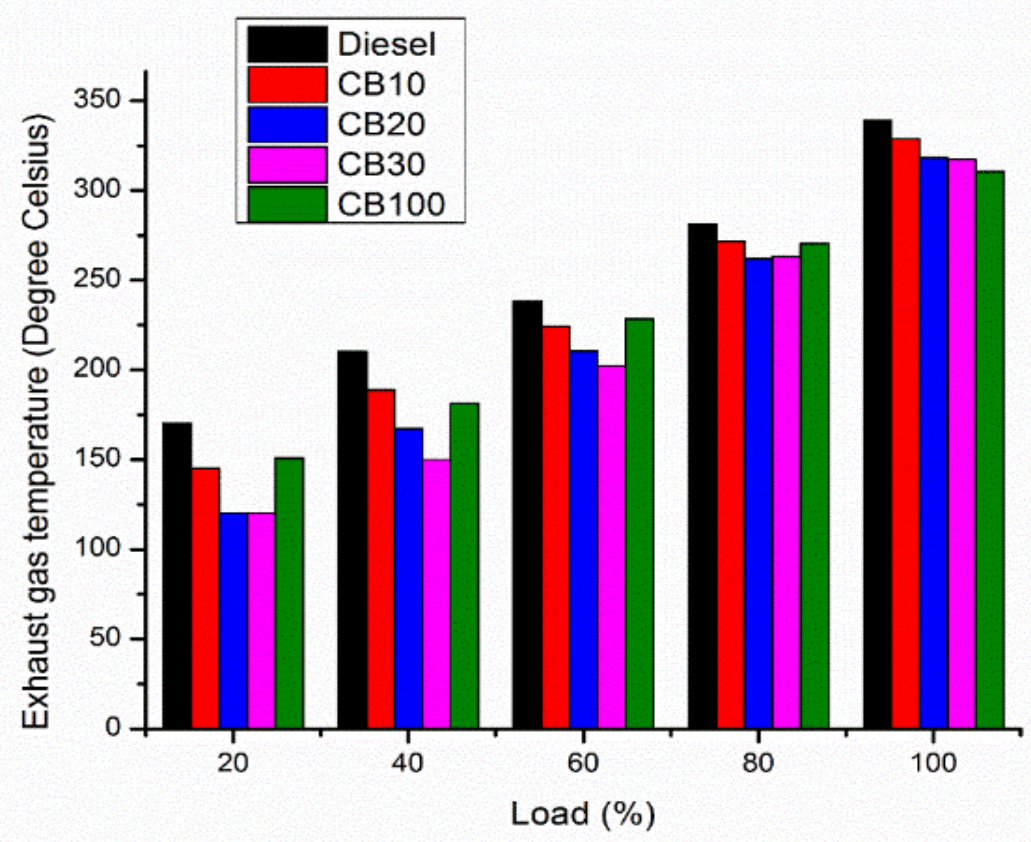

Fig -8: Exhaust gas temperature v/s Load 


\section{CONCLUSION}

The single cylinder compression ignition engine was worked successfully using methyl ester of Canola oil as the soul fuel. The following conclusions are obtained on the base of experimental results.

1. The properties of pure Canola biodiesel (CB100) and its blends (CB10, CB20, CB30) has satisfied result obtained as per ASTM D-6751, EN-14214, and IS-15607 standards of biofuels policy.

2. At $20 \%$ and $40 \%$ loading condition, the Canola biodiesel and it's all blends have higher brake thermal efficiency than diesel. This happens because Canola biodiesel have containing $10 \%$ more oxygen content than diesel.

3. After examine results obtained at all loading condition CB 20 is the best blend because brake thermal efficiency near about pure diesel.

4. Fuel consumption for CB20, CB30 and CB100 blends has lower fuel consumption at $20 \%$ and $40 \%$ load.

5. It is observed that at all loads condition exhaust gas temperature of CB30 has minimum so it decrease NOx emission.

So we have concluded that without any compromise with the given standard performance has obtained without any modification in compression ignition engine so in the future Canola biodiesel alternative fuel.

\section{REFERENCES}

[1]. Murari Mohon Roy, Majed Alawi and Wilson Wang, "Effects of Canola Biodiesel on a DI Diesel Engine Performance and Emissions", International Journal of Mechatronics Engineering IJMME-IJENS Vol:13 No:02, 2013, pp.46-53.

[2]. D. Subramaniam, A. Murugesan, A. Avinash, "Comparative estimation of C.I. engine fuelled with methyl esters of punnai, neem and waste cooking oil", International Journal of Energy and Environment, Volume 4, Issue 5, 2013 pp.859-870.

[3]. Sandeep Kumar Duran, Maninder Singh, Hardeep Singh, "Karanja and Rapseed Biodiesel: An Experimental Investigation of Performance and Combustion Measurement for Diesel Engine", International Journal of Science \& Engineering Research, Volume 6, Issue 1, January-2015, pp. $295-299$.

[4]. Sandeep Kumar Duran, Maninder Singh, Hardeep Singh, "Performance and Combustion Characteristics of Single Cylinder Diesel Engine Fuelled With Blends of Karanja Biodiesel and Diesel", International Journal of Mechanical Engineering and Technology (IJMET), Volume 5, Issue7, July (2014), pp.160-170.

[5]. P.Sreenivas, Venkata Ramesh Mamilla, K.Chandra Sekhar, "Development of Biodiesel from Castor oil", International Journal of Energy Science, 2011, pp.192-197.

[6]. U. Santhan Kumar, K. Ravi Kumar, "Performance, Combustion and Emission Characteristics of Corn oil blended With Diesel", International Journal of Engineering
Trends and Technology (IJETT) - Volume 4 Issue 9-Sep 2013, pp. $3904-3908$.

[7]. Ali Kahraman, Hidayet Oguz, IIker Ors, Ozgur Solmaz, "Effect of Cottonseed oil Methyl ester on the Performance and Exhaust Emissions of a Vehicle", International Journal of Automotive Engineering and Technologies, 2013, pp. 104 -110 .

[8]. Akhihiero E.T., Oghenejoboh K.M., Umukoro P.O., "Effect of Process Variables on Transesterification Reaction of Jatropha Curcas Seed Oil for the Production of Biodiesel", International Journal of Emerging Technology and Advanced Engineering, 2008, pp. 388-393.

[11]. Bobade S.N., Khyade V.B., "Preparation of Methyl Ester (Biodiesel) from Kananja (Pongamia Pinata)", International Science Congress Association, 2012, pp. 43 50.

[12]. N.P. Rathod, S.M. Lawankar, "Comparative Study on Use of Biodiesel (Methyl Ester Kusum oil) and Its Blends in Direct Injection CI Engine - A Review", International Journal of Emerging Technology and Advanced Engineering, 2013, pp. $254-259$.

[13]. V. Rambabu, Dr. V.J.J. Prasad, K. Prasada Rao, "Performance and Emission Analysis of DI - Diesel Engine Using Neat Linseed Methyl Ester Along With Methanol as Dual Fuel", 2012, pp. 35 -39.

[14]. Dilip Kumar Bora, L.M Das, M.K.G Babu, "Storage Stability of Mahua Oil Methyl ester", Journal of Science \& Industrial Research, 2009, pp. 149 - 152.

[15]. M. Abdel fatah, H.A. Farag, M.E. Ossman, "Production of Biodiesel from Non - Edible Oil and Effect of Blending With Diesel on Fuel properties", International Journal (ESTIJ), ISSN: 2250 - 3498, 2012, pp. 583 - 591.

[16]. Sanjay Basumatary, "Transesterification with Heterogeneous Catalyst in Production of Biodiesel", Journal of Chemical and Pharmaceutical Research, ISSN: 09757384, CODEN (USA): JCPRC5, 2013, pp. 1-7.

[17]. Suman Singh, P.K. More, Kirtiraj Gaikwad, "Standardization of Process Parameter for Neem Oil \& Determination of Properties for Using as a Fuel", Journal of Chemical and Pharmaceutical Research, 2013, pp. 1-7.

[18]. Jawad Nagi, Syed Khaleel Ahmed, Farrukri Nagi, "Palm Biodiesel an Alternative Green Renewable Energy for the Energy Demand of the Future", ICCBT 2008, pp. 79 -94 .

[19]. I.M. Atadashi, M.K. Aroua, A.R. Abdul Aziz, N.M.N. Sulaiman, "Renewable and Sustainable Energy Reviews", Elsevier, 2012, pp. 3275-3285.

[20]. Nor Hazwani Abdullah, Sulaiman Haji Hasan, and Nurrul Rahmash Mohd Yusoff, "Biodiesel Production Based on Waste Cooking Oil (WCO)", International Journal of Materials Science and Engineering Vol. 1, No. 2, 2013, pp. $94-99$.

[21]. Melese Tesfaye Firrisa, Irisn van Duren, Alexey Voinov, "Energy Efficiency for Rapeseed Biodiesel Production in Different Farming System”, Springer, 2013, pp. 1- 17.

[22]. H.S. Pali, N.Kumar, "Biodiesel Production from Sal (Shorea Robusta) Seed Oil”, NIET Journal of Engineering \& Technology, Vol. 5, 2014, pp. $24-29$. 
[23]. Maria I. Martins, Ricardo F. Pires, Magno J. Alves, Carla E. Hori, etc, " Transesterification of Soybean Oil for Biodiesel Production using Hydrotalcite as Basic Catalyst", The Italian Association of Chemical Engineering (AIDIC), Vol.32, 2013, pp. $817-822$.

[24]. Alemayehu Gashaw, Abile Teshita, "Production of Biodiesel from Waste Cooking Oil and Factors Affecting its Formation: A review", International Journal of Renewable and Sustainable Energy, 2014; 3(5): 92-98.

[25]. P.V. Rao, "Effect of p\Properties of Karanja Methyl ester on Combustion and NOx Emission of a Diesel Engine", Journal of Petroleum Technology and Alternative Fuel vol. 2(5), 2011, pp. $63-75$.

[26]. Ram Chandra, Virendra K. Vijay, Parchuri M.V. Subbaro, "A study on Biogas Generation from Non-edible Oil Seed Cakes: Potential and Prospects in India", The 2nd Joint International Conference on "Sustainable Energy and Environment (SEE 2006)" 21 - 23 November 2006, Bangkok, Thailand, pp. 1-5.

[27]. Rosli Abu Bakar, Semin, Abdul Rahim Ismail, "Fuel Injection Pressure Effect on Performance of Direct Injection Diesel Engines Based on Experiment", American Journal of Applied Science 5 (3) : 197 - 202, 2008.

[28]. B. Deepanraj, C. Dhanesh, R. Senthil, M. Kannan, "Use of Palm Oil Biodiesel Blends as a Fuel for Compression Ignition Engine", American Journal of Applied Science 8 (11):, 2011 pp. 1154 - 1158.

\section{BIOGRAPHIES}

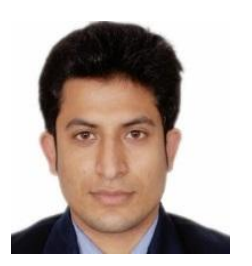

Mr. Amrinder, M.Tech research scholar (thermal engineering) from Lovely Professional University and his area of interest in research area is thermal consideration in biofuels.

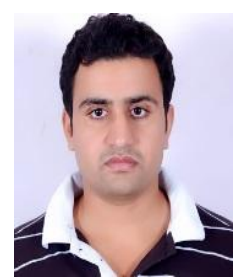

Sandeep Kumar Duran is working an Assistant Professor in Mechanical Department (Thermal Engineering) at Lovely Professional University, Jalandhar. He is pursuing his PhD (Bio Fuel) from NIT Jalandhar. He has 3 years' experience in research and his area of interest includes heat transfer and Bio Fuel. 